\title{
THE IMPACT OF INTERNS TOWARDS CUSTOMER SATISFACTION: A CASE OF BULGARI RESORT AND RESIDENCES BALI, INDONESIA
}

\section{Calvin Tjiputra}

Swiss German University, Tangerang, Indonesia

Article Information

Received: 24 March 2020

Accepted: 20 April. 2020

Published: 18 May 2020

DOI: $10.33555 /$ ijembm.v7i1.125

Corresponding Author:

Calvin Tjiputra

Tangerang, Indonesia

Email: calvintjiputra@yahoo.com

ISSN 2338-8854

eISSN $2620-9918$

\begin{abstract}
The main objective of this research study is to investigate the impact that interns create towards the customer satisfaction of a certain company, which in this case Bulgari Resort and Residences, Bali, Indonesia. The steps that the author took for this research are these following; analyzing literature review and previous studies to backup and support the study, and then the author collects necessary data needed for the research by utilizing questionnaires. Afterwards, the author proceeds to process the data gathered using SPSS to generate the result to answer the main question of the study. The result obtained through this research states that intern does have significant impact towards the customer satisfaction level of Bulgari Resort and Residences, Bali, Indonesia.

Keywords: Service Quality, Internship, Customer Satisfaction, Intern Qualities
\end{abstract}




\section{Introduction}

\subsection{Background}

Hospitality organizations are relying increasingly on students on internships as part of their workforce. This tendency gave students the opportunity to have a trial in companies they so desire working for. Companies especially service based companies such as hospitality, requires an abundance of new, fresh and well educated individuals to keep the company or brand running. Companies in this sector would also want to have a good wage performance ratio from their workers, which leads them to find potential workers with knowledge and skills from schools or universities through internship program. Employing less experienced but educated interns is a new strategy that many companies has been doing.

Recruiting interns would of course create some impact to the company itself, it could be beneficial (Dimitrios, 2006) or disadvantageous (Maertz Jr. et al., 2014). Taking students under the internship programs benefits the company in numerous aspects such as workforce, time and resources. Interns having an internship will be given tasks similar to that of the employees, meaning that they could lighten up the workload of the paid employee and even accelerating the process of a certain works (Tepper \& Holt, 2015).

By undertaking an internship program, students could experience the reality of the working world. Students will gain lots of experience and knowledge by putting their knowledge to practice while working. They will experience trial and errors and would become better as well as becoming more mature. In the process of learning through practice, the interns would affect the service quality of the company they are working for and it will influence customers' satisfaction and customer perception of the brand. Based on the author's investigation during the period of internship in July 2014 until the beginning of January 2015, interns have the same responsibility as the permanent workers. The responsibilities given to each individuals depends on their own work field, which in this case was in the housekeeping department. Some of the interns' responsibilities in the housekeeping department were making sure that the rooms are cleaned and refreshed according to the company's standards and to deliver whatever the guests requested to ensure guest satisfaction. Accordingly, both permanent workers and interns are expected to perform at the same level of excellence and would directly have contact with the guests which means that both interns and permanent workers will influence customers' satisfaction through the quality of service that they perform. Regarding this, the author wants to investigate the significance of hiring interns towards the company's service quality and their customers' satisfaction.

\subsection{Research Problems}

In the past few years, the number of students recruited by companies shows a healthy growth, this means that there are more and more companies that favors the young and fit to work for their companies. The growth also implies that students are interested in the internship programs offered to them. However, this situation could potentially create some problems which the author himself have faced during the internship period. As an intern, the author acts and are treated as employees, meaning that both the permanent employees and the author himself, will undoubtedly affect the quality of service therefore affecting customers' satisfaction. With the given circumstances, problematic questions are beginning to surface, for instance; how significant is the impact given by the interns towards the customer satisfaction, and is the internship program advantage- 
ous for both parties or is it the other way around?

\section{Literature Review}

\subsection{Recruitment and Internship}

\subsubsection{Recruitment}

Recruiting is the act of identifying potential candidates to employ that might be fit to fill the vacancies within a company. This is one of the first few steps that a company will take to employ the right employee. Recruitment could be done in three ways, internally, externally or outsourcing (Hayes \& Ninemeier, 2009).

\subsubsection{Internship}

Employees or human workforce are essential in the hospitality industry because services are intangible. Accordingly, hospitality companies would need trained and educated workforce to deliver their service products. Hiring qualified employees would cost a lot of money and would cost a lot of time, which is probably why companies are now taking in students to work for their companies. Although inexperienced, the students have knowledge and potential and could be a promising future employee. There are reasons why internships are favorable nowadays, and we could see it from the different perspective of the parties participating in the internship programs. The perspective includes the point of view of students, education institution and employing company (Tepper \& Holt, 2015).

\section{Perspective of Students}

From the perspective of the students, internship program creates a big opportunity for them to expose themselves to the reality of real working situation. Students would gain vast knowledge and would be able to critically compare what they have learned with what they face in the practice. On an internship program, students will be working with employees of the company who has various experience in the field. Working with experienced worker will benefit the students as they would give advice on how to do certain jobs and tasks, providing a very effective on-thejob training for the students (Felicen et al., 2014).

Student sees internships also as one of the way to create a good image of themselves in the company they are working for in the hope of receiving good remarks from the employers that might lead to the students gaining job offering for when they finish their studies. Accordingly, students would want to take internship program with companies that they like or will work for in the future giving them a head start. In some college, internships would gain students a certain amount of points which is also one of the motivation for students to go on an internship (Tepper \& Holt, 2015).

\section{Perspective of Education Institutes}

From the point of view of educational institution, participating in internship program demonstrate their capability of producing intelligent individuals. It shows that the institution is a reliable place to prepare students for their future in the working world. Moreover, by giving students their chances to go on some internships, the institution could strengthen their relationship with the company their students are having an internship with. In addition to that, it would also promote the name of the educational institution as their students could work with well-known companies, giving the institution a competitive advantage over their rivaling education institution (Tepper \& Holt, 2015).

\section{Perspective of Companies}

From the perspective of the companies accepting interns, providing or allowing 
students to have an internship in their company is one of the way to give back to the colleges or universities. It allows the students of the educational institution to be introduced with the real world and also to test or sample the students to see if they have potential to be in the company. By participating in the internship program, a company have the advantage to select promising young talents that may be suitable for their company in the future. Doing so will decrease the amount of money and time it takes for them to look for and recruit individuals to work for them. There are also possibilities that the interns might have some solutions or creativity that might lighten up the workload of the employees or even come up with a breakthrough that may lead the company to a success (Tepper \& Holt, 2015).

\subsubsection{Intern Qualities}

Intern qualities are the characteristics and skills that students must have in order to be considered as a successful intern. Students that tend to have high scores on tests and assignments during their studies in the university, does not mean that they will become a successful intern. Accordingly, the qualities or skills that an intern must have are positive attitude, communication skills, human skills, selfdiscipline, and hospitality technical skills (Anastasios, 2015).

\subsection{Service Quality}

\subsubsection{Definition of Service}

Service could be define as an act or performance or even experience, offered by one individual or party to another individual or party. The product offered are intangible, meaning that it cannot be seen or touch, only experienced. This product called service, unlike other tangible products does not result in one party gaining ownership of the service that they have purchased or trade for. It is also very difficult to market and sell services as it could not be made in advance and stored to be sold later on. Services includes delivery of help, utility or care, an experience, information or other intellectual content (Lovelock, Patterson, \& Walker, 2004).

\subsubsection{SERVQUAL}

SERVQUAL model (Parasuraman, Zeithaml, \& Berry, 1988) is one of the most well-known and used parameters to measure service quality and satisfaction (Dennis et al., 2015). SERVQUAL model has five dimension such a reliability, responsiveness, assurance, empathy, and tangibles. These dimensions are defined as follows:

\section{a. Reliability}

The ability to perform the promised service dependably and accurately.

\section{b. Responsiveness}

The willingness to help customers and to provide prompt service

\section{c. Assurance}

The knowledge and courtesy of employees, and their ability to convey trust and confidence.

\section{d. Empathy}

The provision of caring, individualized attention to customer.

\section{e. Tangibles}

The appearances of physical facilities, equipment, personnel and communication materials.

SERVQUAL model's main purpose is to identify the gaps that exist between company's performance and guest's expectation, which then will lead to either guest satisfaction or dissatisfaction. 


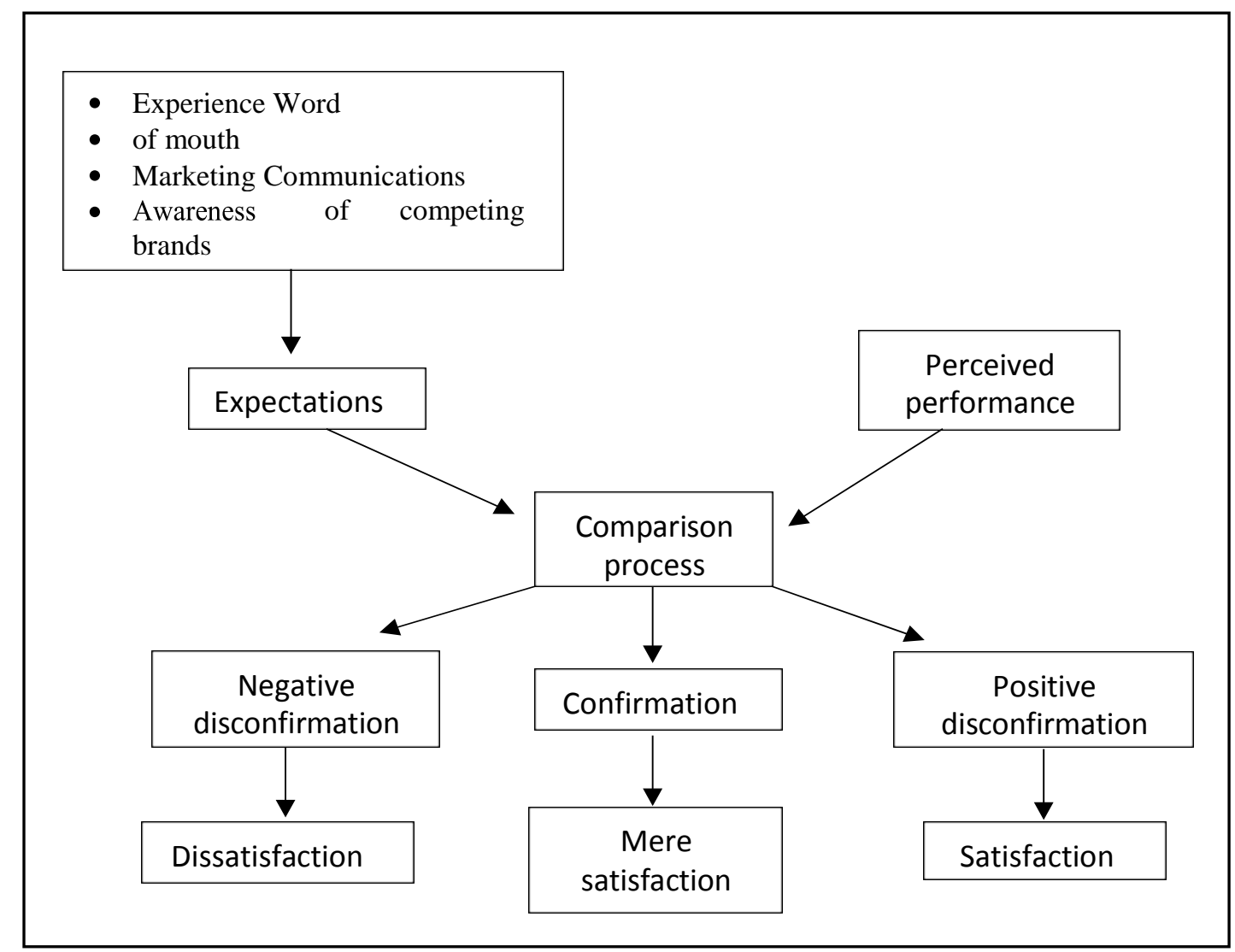

Figure 1. Process to Satisfaction

\subsection{Customer Satisfaction}

\subsubsection{Definition}

Customer satisfaction is the aftermath feeling or affection of the customer after the purchase of the service. The feeling or affection serves as the reaction of the customers that reflects if the service fulfill their needs and wants. The range of the evaluation ranged from disgust, dissatisfied, satisfied and beyond satisfied. This ranges may vary depending on the customers, for different customers has different expectation level towards the services that are being offered.

Customer satisfaction is very crucial in this industry because the customers could easily move from one brand to another, which is why it is essential for a hospitality company to make sure that their customers remain at least satisfied. However, keeping customers on satisfied level could be risky, for there is a possibility for them to move to a rivaling company that offers similar product and services. Accordingly, to keep the customers loyal, a company must always look for a way to improve their services to improve guest loyalty. (Lovelock, Patterson, \& Walker, 2004).

\subsubsection{Factors Influencing Satisfaction}

Customer satisfaction does not happen for no reason. As figure 1 has shown, there are several major factors or steps that influence customers' satisfactions. Before purchasing a service based product, customers would refer to their past experience, what other people says, how the company market itself, and other companies offering similar products of services. This would then create expectations in the mind of the customers. With their expectations in mind, the customers would then proceed to purchase the product of services. Post 
receiving or experiencing the service, the customer would then compare it with their initial expectations. If the services given by the company meets their expectations, they would be mere satisfied. If the services given to them is different, they would undertake a disconfirmation. If the services received by the customers are below their expectations, it would become a negative disconfirmation, and if the service given to the customer exceeds their expectations, it would become a positive disconfirmation (Bowie \& Buttle, 2011; Lovelock, Patterson, \& Walker, 2004).

\subsubsection{Importance of Satisfaction}

The success of a hospitality company relies on how well they satisfy their customers. When customers do not feel content with the product or services given by a company, they could easily turn to another company to get what they desire. If the customer feels dissatisfied, it will cause the company abig loss as they would never return and there are possibilities that they may talk badly about the company, resulting in the company losing its reputation (Bowie \& Buttle, 2011).

On the contrary, a satisfied customer would most likely benefits the company. A satisfied customer would possibly tell other people on how well the product or services that a company delivered. This action called word of mouth (WOM) will attract other people that may potentially be a customer to that company. This act of voluntary advertising is one of the benefit a company could gain through satisfying their customers. This kind of advertising have more significant impact compared to traditional marketing (Lovelock, Patterson, \& Walker, 2004).

Another advantage of satisfying customers is that they have a big possibility to return to the company to purchase the same services. Loyal customers like this is very essential for a hospitality company. They know what to expect and how to gain it from the company, making it easier for the employee of the company to satisfy their needs. In addition to that, loyal customers would most likely forgive minor or even major mistakes, giving the company more room to breathe and learn again (Lovelock, Patterson, \& Walker, 2004).

\subsubsection{Principles of Customer Satisfaction}

Satisfied customer would return again and again to experience again what they had before. Meaning that customer satisfaction is related heavily to customer loyalty. Dissatisfied customers would most likely abandon loyalty because they are not pleased or content of the service given to them. In order for a customer to be loyal to a brand, a company needs to exceed their customers' expectations (Lovelock, Patterson, $\&$ Walker, 2004). There are several key factors that would help a company to build a long lasting relationship with its customers (Bowie $\&$ Buttle, 2011).

\section{Choosing the Type of Customers}

To cater and satisfy all types of customer would be impossible, for there are too many differences in terms of needs and wants. Therefore, the first key factor to maintain customer loyalty is to choose which customer the company wants to satisfy. By doing so, the company could focus in identifying and catering the specific needs and wants of certain type of customer, making it easier to maintain a good relationship and communication with the customer (Bowie \& Buttle, 2011).

\section{Meeting the Expectation of Customers}

Accordingly, the company needs to specifically construct their product and services to meet the expectations of the chosen target consumer. To do so, the company needs to identify and analyze what their customers really want and expecting from them. Subsequently, the Accordingly, the company needs to 
specifically construct their product and services to meet the expectations of the chosen target consumer. To do so, the company needs to identify and analyze what their customers really want and expecting from them. Subsequently, the company needs to choose several expectations and wants to be delivered to their customers, because it is going to be difficult if the company decides to cater to all of their customers' expectations and it would result the customer feeling not special at all. This is the second key factor (Bowie \& Buttle, 2011).

\section{Get it Right the First Time}

The third key factor in building a healthy relationship with the customer is to get it right first time. After successfully pinpointing what the customers wants and expects, the company needs to deliver it to the customer in the first opportunity available. This will create a strong first impression to the customer, also it would increase their perception of the brand. Delivering what the customer wants and expect or even exceeding what they expect constantly, would almost guarantee their loyalty to the company or the brand (Bowie $\&$ Buttle, 2011).

\section{Recovery Policies and System}

The last key to sustain a good relationship with the customer is to establish a wellplanned recovery policies and system. No matter how big or strong the brand of a company is, mistakes and failures are unavoidable as they are unpredictable, which is why a failsafe procedure needs to be generated. The reason for it is so that even when a customer feels disappointed, the company still have some backup strategy on how to make the customer feels better about the given product and services (Bowie \& Buttle, 2011).

\subsubsection{Consumer Behavior}

In order to deliver better services to the customers, service companies such as hotels, needs to understand the process or phases that customers had to go through before deciding to purchase a specific service from a brand of hotel. This phase or process is called consumer decision process. The process consists of 3 main stages, the pre-purchase stage, the consumption stage, and the post-purchase stage. Utilizing consumer decision process analysis will help companies to better understand the behavior of their customers (Bateson \& Hoffman, 2008).

\section{The Pre-Purchase Stage}

The pre-purchase stage includes every kind of activities that a customer goes through before deciding to purchase a particular service. This stage could be divided into four main parts, stimulus, problem awareness, information search and evaluation of alternatives. The first part, stimulus, refers to when customers are stimulated buy the product or services. There are three stimulation cues, commercial cues, social cues, and physical cues. Customers might be attracted to a certain product or services when they see or hear about an advertisement of a product, this is commercial cues. Social cues refer to when an individual are influence by their friends in their social group or their significant others to acquire a product or service. Unlike the first two cues, physical cues are not influenced by external factors. Physical cues are stimulation that comes from an individual's biological needs such as thirst and hunger (Bateson \& Hoffman, 2008).

The second part of the pre-purchase stage is problem awareness. This part ensues when an individual feels or realize that they need to do something or to get something. During this phase, the consumer will examine if what they need and want are available to be purchased. This will lead the consumer into the third phase of pre- purchase stage which is information search. In this phase the 
consumer will be searching about the product or services that are related to what they desire. The consumer will either try to recall a service provider that they have had experienced before or try to search externally by utilizing the internet, asking for advice from friends and families. The phase that comes next is evaluation of alternatives. In this phase consumer would compare the information that they had gathered in order to find the best solution to satisfy their needs and wants (Bateson \& Hoffman, 2008).

\section{The Consumption Stage}

The second stage of consumer decision process is the consumption stage. This stage is highly influenced by the first stage for this stage could only happen if the consumer is stimulated enough to search for information regarding their needs and wants and then finally comparing the information they had gathered until they ultimately choose the most suitable option available. The decision to consume or purchase a product or service is also based on the expectation of the consumer and what the consumer perceive from a brand.

The perception and expectation of the consumer might be influenced by their finding in the information search phase (Bateson \& Hoffman, 2008).

\section{The Post-Purchase Stage}

Finally, consumer will go through the last phase of consumer decision process which is the post-purchase stage. This stage is where the consumer evaluates what they had experience from purchasing a product or service. The consumer would compare the value for money that they got from the experience. The main process for consumer in this stage is to compare and analyze if the service that they get matches their perception and expectations. To ensure consumers that they have chosen the right company to satisfy their needs and wants, companies usually utilizes customer services to handout customer satisfaction surveys in order to gain insights on how satisfied the customers are. The reason behind it is to improve and develop the company even more so that it would suit their customers even more (Bateson \& Hoffman, 2008).

\subsubsection{Customer Satisfaction Measure- ment}

Customers are the measurement of how well a company is doing. When their customers are satisfied, it means that they are successful, and vice versa which is why it is crucial to measure the level of customer satisfaction. The feeling of satisfaction depends primarily to expectations of the customers itself. Customer being satisfied could only be achieved through meeting their expectations or even exceeding it. For example, if a customer has low expectation, even the most standard service would suffice. On the other hand, when a customer has a high expectation, standard service would be disappointing for them.

Although customer satisfaction relies heavily on what the customer feels about the service given to them, there is a measurement that could calculate and identify a company's strengths and weaknesses, called SERVQUAL. The data of a company's strengths and weaknesses can be used to measure the level of service quality of a company and how well does the current quality of service of the company meets their customers' expectations. SERVQUAL is divided into five dimensions, the tangibles dimension, the reliability dimension, the responsiveness dimension, the assurance dimension, and the empathy dimension (Bateson \& Hoffman, 2008). The way it works is that there will be a series of questions or statements for the respondents to answer, and each of the questions or statements are tailored to measure one of the five SERVQUAL dimensions. Each dimension will have several questions or statements 
with different approach or simple paraphrasing to minimalize errors and to make the results as objective as possible.

\subsection{Research Model}

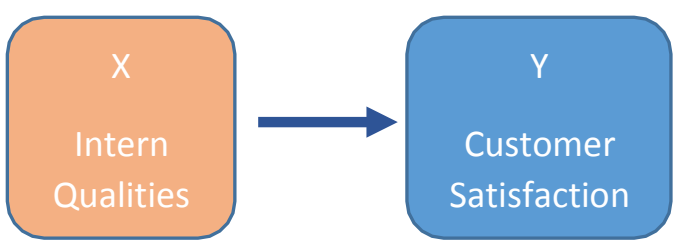

Figure 2. Research Model

H.o: Interns have no significant impact towards the customers' satisfaction. $\mathrm{H}_{.1}$ : Interns have significant impact towards the customers' satisfaction.

\section{Research Methodology}

\subsection{Scope of Study}

\subsubsection{Unit Analysis}

The unit analysis of this research study is Bulgari Resort and Residences, Bali, Indonesia. The reason behind this is that the author has had experience in the company, therefore the author has some insights towards the operational of the company

\subsubsection{Unit Observation}

The unit that will be observed in this research study are the guests of Bulgari Resort and Residences, Bali, Indonesia. The answers from the guests will be related towards SERVQUAL dimensions. Another unit that will be observed are the managers and supervisors of each operating departments.

\subsection{Type of Study}

The type of study that the author is going to use in this research study is purposive descriptive study. In addition to that, the author will also utilize qualitative approach to gain more in depth understanding towards the objective of the study. Purposive descriptive study aims to define and explain phenomenon or to describe a characteristic of a certain target population.
Descriptive study also analyzes the correlations between variables or indicators (Cooper \& Schindler, 2014).

\subsection{Population and Samples}

For this research, the author employs a non-probable purposive sample, as the sample of the study has already been identified. The population of this study would be those who had stayed or visited Bulgari Resort and Residences Bali. The amount of the population is unknown leading towards the sample size being also unknown, therefore the author will be utilizing proportion parameter sampling with $90 \%$ confidence level and $10 \%$ margin of error, accordingly the $\mathrm{Z}$ value will be 1.645 .

$$
\begin{array}{r}
(Z 1 \propto) 2 \\
n=\frac{2}{4(e)^{2}} \\
n=\text { Sample size } \\
Z=Z \text { value } \\
\propto=\text { Standard deviation } \\
\mathrm{E}=\text { Margin of error } \\
n=\frac{(1.645) 2}{4(10 \%)^{2}} \\
n=\frac{2.71}{4(0.01)} \\
n=67.65
\end{array}
$$

With the calculation using the proportion parameter sampling method, the sample size needed for the research is 67.65 , rounded up to 68 . As for the managers and supervisors, the respondents would be food and beverages managers and supervisors, human resources manager, front office manager and supervisors and housekeeping manager and supervisors, also some senior staffs that has handled and directed the interns. 


\subsection{Operational Variable}

Table 1 below shows the Operational Variable.

Table 1. Operational Variable

\begin{tabular}{|c|c|c|c|c|}
\hline Variable(s) & Indicator(s) & Source(s) & Statements & Scale \\
\hline \multirow{14}{*}{ 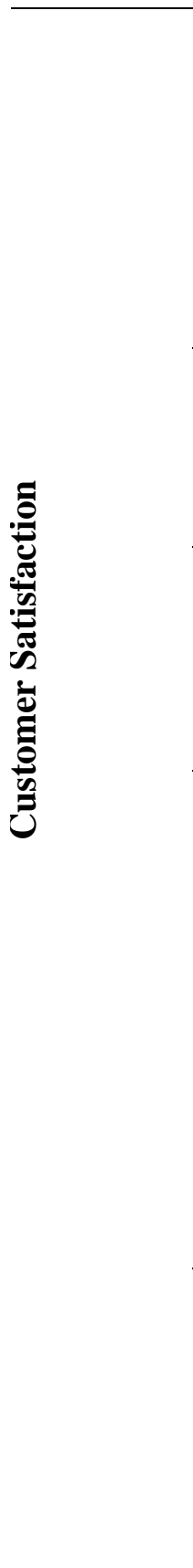 } & \multirow[t]{3}{*}{ Reliability } & \multirow[t]{3}{*}{$\begin{array}{l}\text { (Parasuraman, Zeithaml, } \\
\text { \&Berry, 1988) }\end{array}$} & $\begin{array}{l}\text { 1. The staffs responds to my } \\
\text { inquiries timely. }\end{array}$ & Likert \\
\hline & & & $\begin{array}{l}\text { 2. The products and services } \\
\text { meets my expectations. }\end{array}$ & Likert \\
\hline & & & $\begin{array}{l}\text { 3. The staffs know my } \\
\text { preference. }\end{array}$ & Likert \\
\hline & \multirow[t]{2}{*}{ Tangibles } & \multirow[t]{2}{*}{$\begin{array}{l}\text { (Parasuraman, Zeithaml, } \\
\text { \&Berry, 1988) }\end{array}$} & $\begin{array}{l}\text { 1. The staffs gave me a } \\
\text { personalized service. }\end{array}$ & Likert \\
\hline & & & $\begin{array}{l}\text { 2. The products and services } \\
\text { meets my expectations. }\end{array}$ & Likert \\
\hline & \multirow[t]{2}{*}{ Responsiveness } & \multirow[t]{2}{*}{$\begin{array}{l}\text { (Parasuraman, Zeithaml, } \\
\text { \&Berry, 1988) }\end{array}$} & $\begin{array}{l}\text { 1. The staffs greet me } \\
\text { properly. }\end{array}$ & Likert \\
\hline & & & $\begin{array}{l}\text { 2. The staffs responds to my } \\
\text { inquiries timely. }\end{array}$ & Likert \\
\hline & \multirow[t]{4}{*}{ Assurance } & \multirow[t]{4}{*}{$\begin{array}{l}\text { (Parasuraman, } \\
\text { Zeithaml,\&Berry, 1988) }\end{array}$} & $\begin{array}{l}\text { 1. The staffs gave me a } \\
\text { personalized service. }\end{array}$ & Likert \\
\hline & & & $\begin{array}{l}\text { 2. The staffs knows my } \\
\text { preference. }\end{array}$ & Likert \\
\hline & & & $\begin{array}{l}\text { 3. The products and services } \\
\text { meets my expectations. }\end{array}$ & Likert \\
\hline & & & $\begin{array}{l}\text { 4. The service given is } \\
\text { satisfactory. }\end{array}$ & Likert \\
\hline & \multirow[t]{3}{*}{ Empathy } & \multirow[t]{3}{*}{$\begin{array}{l}\text { (Parasuraman, } \\
\text { Zeithaml,\&Berry, 1988) }\end{array}$} & $\begin{array}{l}\text { 1. The staffs greet me } \\
\text { properly }\end{array}$ & Likert \\
\hline & & & $\begin{array}{l}\text { 2. The staffs gave me a } \\
\text { personalized service. }\end{array}$ & Likert \\
\hline & & & $\begin{array}{l}\text { 3. The staffs knows my } \\
\text { preference }\end{array}$ & Likert \\
\hline
\end{tabular}




\begin{tabular}{|c|c|c|c|c|}
\hline Variable(s) & Indicator(s) & Source(s) & Statements & Scale \\
\hline \multirow{11}{*}{ 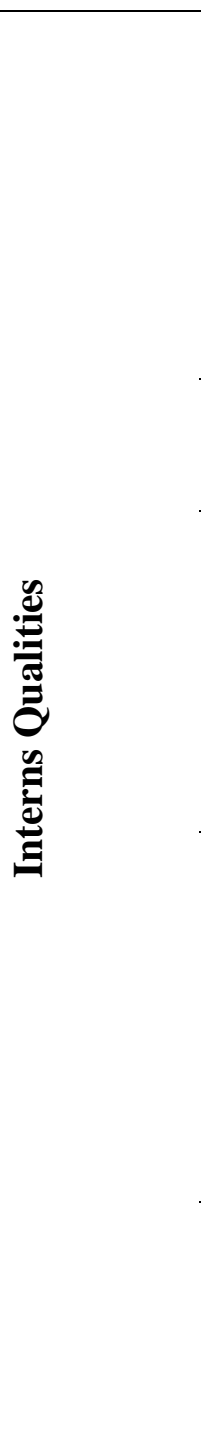 } & \multirow[t]{3}{*}{ Positive attitude } & \multirow[t]{3}{*}{ (Anastasios, 2015) } & $\begin{array}{l}\text { 1. The staffs greets me } \\
\text { properly. }\end{array}$ & Likert \\
\hline & & & $\begin{array}{l}\text { 2. The interns took their job } \\
\text { seriously. }\end{array}$ & Likert \\
\hline & & & $\begin{array}{l}\text { 3. The interns impact the } \\
\text { service quality of the } \\
\text { company positively. }\end{array}$ & Likert \\
\hline & $\begin{array}{l}\text { Communication } \\
\text { skills }\end{array}$ & (Anastasios, 2015) & $\begin{array}{l}\text { 1. The interns help promote } \\
\text { the property to the guests. }\end{array}$ & Likert \\
\hline & \multirow[t]{2}{*}{ Human skills } & \multirow[t]{2}{*}{ (Anastasios, 2015) } & $\begin{array}{l}\text { 1. The interns motivate the } \\
\text { employees to do their } \\
\text { work even better. }\end{array}$ & Likert \\
\hline & & & $\begin{array}{l}\text { 2. The interns give the } \\
\text { employees adifferent } \\
\text { perspective of working. }\end{array}$ & Likert \\
\hline & \multirow[t]{3}{*}{ Self-discipline } & \multirow[t]{3}{*}{ (Anastasios, 2015) } & $\begin{array}{l}\text { 1. The interns operate under } \\
\text { the SOP of the company. }\end{array}$ & Likert \\
\hline & & & $\begin{array}{l}\text { 2. The interns show growth } \\
\text { during the training. }\end{array}$ & Likert \\
\hline & & & $\begin{array}{l}\text { 3. The interns work well } \\
\text { under pressure. }\end{array}$ & Likert \\
\hline & \multirow[t]{2}{*}{$\begin{array}{l}\text { Hospitality } \\
\text { technical skills }\end{array}$} & \multirow[t]{2}{*}{ (Anastasios, 2015) } & $\begin{array}{l}\text { 1. The interns are properly } \\
\text { trained. }\end{array}$ & Likert \\
\hline & & & $\begin{array}{l}\text { 2. The interns performs } \\
\text { as good as the } \\
\text { expected. }\end{array}$ & Likert \\
\hline
\end{tabular}




\subsection{Classical Assumption Test}

Classical assumption test is a test that statistically measures and determine the relation between variables (Ainiyah, Deliar, \& Virtrina, 2016). The main reason to utilize classical assumption test is to minimalize and even to prevent errors from happening in the regression test.

\subsubsection{Normality Test}

Normality test is a statistical test, used to identify and determine whether the data collected has normal distribution (Santoso, 2010). For the data to be viable to be used for regression, it has to be distributed normally, meaning that the data are spread out evenly therefore it can represent the population that the researcher are trying to study. In order to determine if the data collected are normal, One-Sample Kolmogorov-Smirnov test will be carried out. The data will be considered as normal if the result gained through the utilization of One-Sample Kolmogorov-Smirnov is higher than or equal to the significant value of 0.10 .

\subsubsection{Normality Test Result}

From table 2 it is shown that the Sig value gained through the utilization of OneSample Kolmogorov-Smirnov is 0.142 . According to the theory on the previous chapter regarding normality test, the data are considered as normal because the result exceeds the probability value of 0.10 .

\subsubsection{Linearity Test}

Linearity test aims to determine whether there are significant relation between the variables (Ferraro, Colubi, \& Giordani, 2010). Linearity also has an equation called linear equation with $\mathrm{Y}=\mathrm{a}+\mathrm{b}(\mathrm{X})$ as its equation. Through calculation, it is known that the equation for this research is $\mathrm{Y}=0.04447 * \mathrm{X}+38.95$. The equation can be translated as, the level of customer satisfaction will be affected by the qualities of interns. In other words, when intern qualities improve, the level of customer satisfaction would also increase hand in hand.

Table 2. Normality Test Result

One-Sample Kolmogorov-Smirnov Test

\begin{tabular}{|ll|r|}
\hline & & $\begin{array}{r}\text { Unstandardiz } \\
\text { ed Residual }\end{array}$ \\
\hline $\mathrm{N}$ & Mean & 30 \\
Normal Parameters & a,b & .0000000 \\
Most Extreme Differences & Std. Deviation & 3.56664030 \\
& Absolute & .139 \\
& Positive & .105 \\
Test Statistic & Negative & -.139 \\
Asymp. Sig. (2-tailed) & & .139 \\
\hline
\end{tabular}
a. Test distribution is Normal.
b. Calculated from data.
c. Lilliefors Significance Correction. 
Table 3. Linearity Test Result

ANOVA Table

\begin{tabular}{|c|c|c|c|c|c|c|c|}
\hline & & & $\begin{array}{l}\text { Sum of } \\
\text { Squares }\end{array}$ & df & Mean Square & $\mathrm{F}$ & Sig. \\
\hline \multirow[t]{5}{*}{$y^{*} x$} & Between Groups & (Combined) & 716.240 & 20 & 35.812 & 1.443 & .135 \\
\hline & & Linearity & 4.795 & 1 & 4.795 & .193 & .662 \\
\hline & & Deviation from Linearity & 711.446 & 19 & 37.445 & 1.509 & .112 \\
\hline & Within Groups & & 1638.174 & 66 & 24.821 & & \\
\hline & Total & & 2354.414 & 86 & & & \\
\hline
\end{tabular}

Table 3 above shows the result of linearity test by utilizing SPSS. The result from the test is 0.112 . The result 0.112 is bigger than the significant value of 0.10 , meaning that there is significant relation between the two variables.

\subsection{Hypothesis Test}

Hypothesis test is a statistical test utilized to determine if there is evidence indicating the existence of significant relation between the variables. For this research study, the author will be using simple linear regression. The main measurement for this test is the significant value which in this case is 0.10 . If the hypothesis result is greater than or equal to 0.10 , then the $\mathrm{H}_{0}$ is accepted, and if the result is less than 0.10 , then the $\mathrm{H}_{0}$ is rejected.

\section{Results and Discussions}

\subsection{Analysis of The Impact of Intern Qualities Towards Customer Satisfac- tion}

Intern qualities refers to the characteristics and skills that students as interns requires to be considered as successful interns. The five major points that affects intern qualities are positive attitude, communication skills, human skills, self- discipline, and hospitality technical skills (Anastasios, 2015).

\subsubsection{Positive Attitude}

From the table 4 , it can be seen that the mean of each of the statements are nearing the number four on the Likert scale.

Table 4. Positive Attitude

\begin{tabular}{ll}
\multicolumn{1}{c}{ Statements } & Mean \\
\hline The staffs greet me properly. & 3.57 \\
\hline $\begin{array}{l}\text { The interns took their job } \\
\text { seriously. }\end{array}$ & 3.59 \\
\hline $\begin{array}{l}\text { The interns impact the service quality } \\
\text { of the company positively. }\end{array}$ & 3.53 \\
\hline Mean & $\mathbf{3 . 5 6}$
\end{tabular}

Moreover, the mean of the three statements referring to positive attitude is 3.56 , in other words is on the positive side. This results means that most of the respondents agrees that the interns have already got positive attitude at the time they are training in the company.

\subsubsection{Communication Skills}

The statement "The interns help promote the property to the guests" and "The staffs greet me properly" refers to communication skills. The mean of these two statements is 3.4 , meaning that it is on the positive side of the scale. On both of the statements, $100 \%$ of the respondents agrees or strongly agrees. This results means that the interns are able to communicate effectively while promoting the property. 


\subsubsection{Human Skills}

On the side of human skills, it could be seen from the table below that the first statement has a much lower mean than the second statement.

Table 5. Human Skills

\begin{tabular}{ll}
\hline \multicolumn{1}{c}{ Statements } & Mean \\
\hline $\begin{array}{l}\text { The interns motivate the } \\
\text { employees to do their work even } \\
\text { better. }\end{array}$ & 2.70 \\
\hline $\begin{array}{l}\text { The interns give the employees a } \\
\text { different perspective of working. }\end{array}$ & 3.50 \\
\hline \multicolumn{2}{c}{ Mean } \\
\hline
\end{tabular}

This could mean that while the interns give different perspective to the employees, the interns do not really motivate the employees. Accordingly, as a human being, the interns are capable of shifting people's perspective but unable to motivate them to do more.

\subsubsection{Self-Discipline}

Table 6 below shows the statements referring to self-discipline.

Table 6. Self-Discipline

\begin{tabular}{ll}
\hline \multicolumn{1}{c}{ Statements } & Mean \\
\hline $\begin{array}{l}\text { The interns operate under the } \\
\text { SOP of the company. }\end{array}$ & 3.46 \\
\hline $\begin{array}{l}\text { The interns show growth during the } \\
\text { training. }\end{array}$ & 3.30 \\
\hline $\begin{array}{l}\text { The interns work well under } \\
\text { pressure. }\end{array}$ & 2.96 \\
\hline \multicolumn{2}{c}{ Mean } \\
\hline
\end{tabular}

The company has a very elaborate standard operating procedures that all staffs must follow, including the interns. According to the staffs, the interns fully operate under the SOP of the company in performing day to day tasks as the high value of mean represent. Although all day to day operations are guided by the SOP, there will be moments in work that will apply some pressure even towards the staffs. Even though the mean of the statement is the lowest of the bunch, according to the staffs, most of the interns work quite well under pressure, although some of them cracks under pressure as can be seen by the low rating of the mean.

All in all, the interns could be said as quite discipline as they not only follow the SOP but they also work in real working condition. These conditions help the interns to grow as they train, making them an even better human being. Concordantly, with a mean of 3.24 , the interns can be declared as individuals with moderate to high level of self-discipline.

\subsubsection{Hospitality Technical Skills}

The table 7 shows the statements referring to hospitality technical skills.

Table 7. Hospitality Technical Skills

\begin{tabular}{|c|c|}
\hline Statements & Mean \\
\hline The interns are properly trained. & 3.46 \\
\hline $\begin{array}{l}\text { The interns perform as good as the } \\
\text { expected. }\end{array}$ & 2.87 \\
\hline Mean & 3.17 \\
\hline
\end{tabular}

The first statement of this indicator has a mean of 3.46 implicating a high number of respondents agreeing to the statement. Moreover, $100 \%$ of the staffs agreed that the interns working on the property are trained properly, before and during the internship. Although properly trained, the mean on the statement "The interns perform as good as expected" is only 2.87 , which is not quite high compared with the first statement. The lower mean could imply that some of the interns does not perform as good as expected. In fact, as much as $33.33 \%$ of the respondents disagree with the statement. This could be the result of the interns not being able to work under pressure as stated on the previous table. All in all, the mean of both statements is 3.17 , is quite high, implying that the interns mostly have sufficient hospitality technical skills. 


\subsection{Hypothesis Test Simple Regression Linear}

The table below shows the result of the hypothesis test which is 0.084 .

Table 8. Hypothesis Test Result

Coefficients $^{\mathrm{a}}$

\begin{tabular}{|c|c|c|c|c|c|c|}
\hline \multirow[b]{2}{*}{ Model } & & \multicolumn{2}{|c|}{ Unstandardized Coefficients } & \multirow{2}{*}{$\begin{array}{c}\begin{array}{c}\text { Standardized } \\
\text { Coefficients }\end{array} \\
\text { Beta } \\
\end{array}$} & \multirow[b]{2}{*}{$t$} & \multirow[b]{2}{*}{ Sig. } \\
\hline & & $B$ & Std. Error & & & \\
\hline \multirow[t]{2}{*}{1} & (Constant) & 27.712 & 7.113 & & 3.896 & .001 \\
\hline & Total_X & .282 & .157 & .321 & 1.792 & .084 \\
\hline
\end{tabular}

The result of 0.084 is lower than the significant value which is 0.10 . This means that $\mathrm{H}_{0}$ of the research is rejected, and $\mathrm{H}_{1}$ is accepted. In other words, interns have significant impact towards customer satisfaction.

Table 9. Adjusted R Value Table Model Summary

\begin{tabular}{|l|l|r|r|r|}
\hline Model & $\mathrm{R}$ & R Square & $\begin{array}{c}\text { Adjusted } \mathrm{R} \\
\text { Square }\end{array}$ & $\begin{array}{c}\text { Std. Error of } \\
\text { the Estimate }\end{array}$ \\
\hline 1 & $.321^{\mathrm{a}}$ & .103 & .071 & 3.62977 \\
\hline
\end{tabular}

a. Predictors: (Constant), Total_X

Based on the hypothesis test result shown on table $4.6, \mathrm{H}_{0}$ of this research study is rejected. In other words, $\mathrm{H}_{1}$ is accepted, meaning that Interns have significant impact towards the customers' satisfaction. The result from the adjusted $R$ value on the table above also shows that intern qualities has significant relation $(32.10 \%)$ towards customer satisfaction. According to Tepper \& Holt (2015), having interns working on a company will impact the company, whether it is positive (Dimitrios, 2006) or negative (Maertz Jr, Stoeberl, \& Marks, 2014).

\section{Conclusion}

After all the necessary data are collected and processed, a result is achieved, stating that interns do have significant impact (32.10\%) towards the level of customer satisfaction of the guests of Bulgari Resort and Residences, Bali, Indonesia. The other
$67.90 \%$ are factors influencing customer satisfaction that are not related to intern qualities. The following are possible factors that are influencing customer's satisfaction: Customer's perception of a product or service that could be influenced by word of mouth or marketing media; customer's brand awareness; customer loyalty (Lovelock, Patterson, \& Walker, 2004) and other factors that are not discussed on this study. Other limitation is in the statistical power as mention in reviewer comment!

\subsection{Recommendation}

For the managerial side of Bulgari Resort and Residences, Bali, Indonesia, it is recommended to have more senior staff serving on the field rather than more interns. With more staffs on the field, the interns could learn more and the risk or error could be minimized. Moreover, more on the job training that are related to the department the interns are assigned in, that way, they can learn firsthand on what the company expects them to do. Seminar could also prove to be useful as it will instill the moral and vision of the company to the students, so that they will do their job better as they feel that they are part of the company. Accordingly, the students could also be more engaging with the seniors and the guests so that they will gain more knowledge and feedbacks to help them grow as a person and develop their skills as a hotelier.

\section{References}

Ainiyah, N., Deliar, A., \& Virtrina, R. (2016). The Classical Assumption Test to Driving Factors of Land Cover Change in The Development Region of Northern Part of West Java. The International Archives of the Photogrammetry, 41(23), 205-210.

Anastasios, Z. (2015). Hospitality Internship in Cyprus: A Genuine Academic Experience or A Continu- 
ing Frustration? International Journal of Contemporary Hospitality Management, 19(1), 65-77.

Bateson, J. E., \& Hoffman, K. D. (2008). Service Marketing, 4th ed. Mason: South-Western.

Bowie, D., \& Buttle, F. (2011). Hospitality Marketing Principles and Practice, 2nd ed. Oxford: Elsevier.

Carison, C. R., \& Halbrooks, M. C. (2003). Essential Components of a Succesful Internship Program. Westerville: Ohio Nursery \& Landscape Association.

Cooper, D., \& Schindler, P. (2014). Business Research Method, 12th ed. New York: McGraw-Hill Education.

Dennis, A. R., Michael, D. C., Robert, D. N., \& Peter, B. B. (2015). Measuring Service Quality in Misscale Hotels. International Journal of Contemporary Hospitality Management, 27(1), 87-106.

Dimitrios, M. M. (2006). Internships at Greek Universities: An Exploratory Study. Journal of Workplace Learning, 18(1), 28-41.

Felicen, S. S., Rasa, L. C., Sumanga, J. E., \& Buted, D. R. (2014). Internship Performance of Tourism and Hospitality Students: Inputs to Improve Internship Program. International Journal of Academic Research in Business and Social Sciences, 4(6).

Ferraro, M. B., Colubi, A., \& Giordani, P. (2010). A Linearity Test for a Simple Regression Model. Advances in Intelligent and Soft Computing, 77.

Ghozali, I. (2007). Aplikasi Analisis
Multivariat dengan Program SPSS. Semarang: Universitas Diponegoro.

Hayes, D. K., \& Ninemeier, J. D. (2009). Human Resources Management in the Hospitaliy Industry. Hoboken: John Wiley \& Sons, Inc.

Hill, C R., Griffiths, W. E., \& Lim, G. C. (2011). Principles of Econometric, 4th ed. USA: Paperback.

Lovelock, C., Patterson, P., \& Walker, R. (2004). Services Marketing, 3rd ed. Frenchs Forest: Pearson Education Australia.

Maertz Jr, C. P., Stoeberl, P. A., \& Marks, J. (2014). Career Development International, 19. Building successful internships: lessons from the research for interns, schools, and employers, 123-142.

Santoso, S. (2010). Statistik Multivariat. Jakarta: P.T. Elex Media Komputindo.

Tepper, R. J., \& Holt, M. P. (2015). Unpaid Internships: Free Labor or Valuable Learning Experience? Brigham Young University Education \& Law Journal 2015(1), 323352. 